\title{
The Role of Alveolar Edema in COVID-19
}

\author{
Shu Yuan ${ }^{1, *, \dagger}$, Si-Cong Jiang ${ }^{2,+}$, Zhong-Wei Zhang ${ }^{1}$, Yu-Fan Fu ${ }^{1}$, Jing $\mathrm{Hu}^{3}$ and Zi-Lin $\mathrm{Li}^{4}$ \\ 1 College of Resources, Sichuan Agricultural University, Chengdu 611130, China; \\ zzwzhang@126.com (Z.-W.Z.); stefanlife@126.com (Y.-F.F.) \\ 2 Chengdu Kang Hong Pharmaceutical Group Comp. Ltd., Chengdu 610036, China; jiangsc@cnkh.com \\ 3 School of Medicine, Northwest University, Xi'an 710069, China; hujinglzbx@163.com \\ 4 Department of Cardiovascular Surgery, Xijing Hospital, Medical University of the Air Force, \\ Xi'an 710032, China; lizhuoyuanbb@163.com \\ * Correspondence: roundtree@sicau.edu.cn \\ + These authors contributed equally to this work.
}

Citation: Yuan, S.; Jiang, S.-C.;

Zhang, Z.-W.; Fu, Y.-F.; Hu, J.; Li, Z.-L. The Role of Alveolar Edema in COVID-19. Cells 2021, 10, 1897. https://doi.org/10.3390/cells10081897

Academic Editors: Barbara Ruaro,

Francesco Salton and

Marco Confalonieri

Received: 2 July 2021

Accepted: 23 July 2021

Published: 26 July 2021

Publisher's Note: MDPI stays neutral with regard to jurisdictional claims in published maps and institutional affiliations.

Copyright: () 2021 by the authors. Licensee MDPI, Basel, Switzerland. This article is an open access article distributed under the terms and conditions of the Creative Commons Attribution (CC BY) license (https:// creativecommons.org/licenses/by/ $4.0 /)$.

\begin{abstract}
The coronavirus disease 2019 (COVID-19) has spread over the world for more than one year. COVID-19 often develops life-threatening hypoxemia. Endothelial injury caused by the viral infection leads to intravascular coagulation and ventilation-perfusion mismatch. However, besides above pathogenic mechanisms, the role of alveolar edema in the disease progression has not been discussed comprehensively. Since the exudation of pulmonary edema fluid was extremely serious in COVID-19 patients, we bring out a hypothesis that severity of alveolar edema may determine the size of poorly-ventilated area and the blood oxygen content. Treatments to pulmonary edema (conservative fluid management, exogenous surfactant replacements and ethanol-oxygen vapor therapy hypothetically) may be greatly helpful for reducing the occurrences of severe cases. Given that late mechanical ventilation may cause mucus (edema fluid) to be blown deep into the small airways, oxygen therapy should be given at the early stages. The optimal time and blood oxygen saturation $\left(\mathrm{SpO}_{2}\right)$ threshold for oxygen therapy are also discussed.
\end{abstract}

Keywords: SARS-CoV-2; endothelial injuries; ventilation-perfusion mismatch; intravascular coagulation; alveolar edema; oxygen therapy

\section{Introduction}

Since the outbreak of novel SARS-like coronavirus (SARS-CoV-2), over 181,521,067 confirmed cases and 3,937,437 confirmed deaths have been reported globally by the World Health Organization (WHO) as of 1 July 2021. Acute respiratory distress syndrome (ARDS) and the serious complications (mainly multiple organ failure) are the most frequent causes of death [1-4]. However, the main cause of death was not direct ARDS, but the multiple organ failure, such as RNAemia, acute cardiac injury, acute renal injury and septic shock [1-4]. ARDS is a type of respiratory failure whose definition is based on a ratio of arterial oxygen tension to fractional inspired oxygen $\left(P_{\mathrm{a}} \mathrm{O}_{2}: F_{\mathrm{i}} \mathrm{O}_{2}\right)$ of less than $300 \mathrm{~mm} \mathrm{Hg}$ despite a positive end-expiratory pressure of more than $5 \mathrm{~cm} \mathrm{H}_{2} \mathrm{O}[5,6]$, which means that hypoxemia is a necessary condition for the patient to have an ARDS. A longer-time hypoxemia may result in cardiac ischemia, renal ischemia or RNAemia/septic shock, indicating a multiple organ ischemia [1-4]. On the other hand, some features of COVID-19 pneumonia distinguish it from typical ARDS. The patients at early stages often display little breathlessness, despite profound hypoxemia, a symptom referred to as "happy hypoxemia". A report showed dyspnea in only $18.7 \%$ of 1099 hospitalized COVID-19 patients, despite their low ratios of partial pressure of arterial oxygen to percentage of inspired oxygen; in contrast, as high as $86 \%$ of the patients showed abnormal computerized tomography scans [7]. Although the profound hypoxemia was associated with a large intrapulmonary shunt (also different from typical ARDS), alveolar cells are well preserved in COVID-19 relative to typical ARDS [8]. 
In addition to the need for oxygen supply in a high proportion (41\%) of COVID-19 patients [7], 56\% of the patients admitted to intensive care unit (ICU) were given noninvasive ventilation, $76 \%$ of whom required further orotracheal intubation and invasive mechanical ventilation [9]. Nevertheless, in some underdeveloped countries, there is extraordinary shortage of ventilators and extracorporeal membrane oxygenation (ECMO), which may lead to higher mortality rates. More efficient therapies to improve patients' breathing or treatments that could reduce the probability of the occurrence of severe cases need to be developed immediately.

\section{Endothelial Injuries in COVID-19}

The multiple roles of alveolar endothelial and epithelial barriers have been well documented in many lung diseases, such as acute lung injury (ALI), idiopathic pulmonary fibrosis (IPF) and chronic obstructive pulmonary disease (COPD) [5]. However, the role of alveolar injuries in the disease progression of COVID-19 has not been discussed comprehensively so far [10,11].

During the mechanism of dysfunction of the alveolar epitheliums, important roles are related to alveolar epithelial cells type I/II (AEI/AEII). AEII coordinates the host defense mechanisms, not only generating the restrictive alveolar epithelial barrier, but also secreting pulmonary surfactant, which reduces surface tension at the pulmonary air-liquid interface, thereby preventing atelectasis and alveolar edema [10-14]. Furthermore, the innate immune responses to infection of AEII lead both to the cell death by pyroptosis and apoptosis and to the activation alveolar macrophages [10-14]. In addition, the glucocorticoid receptor $\alpha$ acts as a cellular rheostat to ensure that a proper response is elicited by the neuro-endocrine and immune systems [6,15]. Actually, various chronic and acute diseases (including COVID-19) are associated with intensive inflammations [1,2]. Hyperplastic AEII are considered to be an essential part of the epithelialization processes and, consequently, endothelial injury healing [10-14].

The lung's initial response to acute viral infections has been characterized by innate immunity-mediated damages of the alveolar endothelial and epithelial barriers and accumulation of protein-rich edema fluid within the interstitium and alveolus, and then a great decline in oxygen diffusion over the blood-air barrier [5]. Blood flow through severelydamaged units, hereby, constitutes an intrapulmonary shunt and the hypoxia [5]. Acute hypoxia inhibits $\mathrm{Na} / \mathrm{K}$-ATPase function by activating its endocytosis from the plasma membrane to intracellular compartments. The endocytosis process is suggested to be mediated by the accumulation of reactive oxygen species (ROS) in mitochondria. Then ROS promotes the protein kinase C (PKC)-zeta dependent phosphorylation of the $\mathrm{Na} / \mathrm{K}$ ATPase $\alpha$ subunit triggering its endocytosis in a clathrin-AP2 dependent pathway [16]. More prolonged hypoxia may cause the ubiquitination and degradation of $\mathrm{Na} / \mathrm{K}$-ATPase subsequently. As a result, hypoxia inhibits $\mathrm{K}^{+}$channels but activates voltage gated $\mathrm{Ca}^{2+}$ channels, which raises cytosolic $\mathrm{Ca}^{2+}$ levels in pulmonary artery smooth muscle cells (PASMC) and causes vasoconstriction [5,17]. Thus at the tissue level, patients of acute lung injury often develop the hypoxic pulmonary vasoconstriction (HPV), which is an essential protection mechanism of the lung that directs blood perfusion from badly-ventilated to well-ventilated alveoli to optimize gas exchange $[18,19]$. Endothelin- 1 and thromboxane $\mathrm{A}_{2}$ may amplify, whereas prostacyclin and nitric oxide (NO) may moderate this process [19]. In addition, prostacyclin was suggested to be coupled mainly to cyclooxygenase- 1 in acute hypoxia, but to cyclooxygenase-2 in chronic hypoxia [19].

At the subcellular level, mitochondria in PASMC have been considered to be oxygen sensors and initiate HPV [20-24]. Warburg metabolism (a phenomenon firstly found in tumor cells, which almost exclusively use glycolysis to generate energy, even under aerobic conditions) in PASMC mitochondria is initiated by the induction of a pseudo-hypoxic state, where DNA methyltransferase-mediated regulation in redox signaling results in normoxic activation of hypoxia inducible factor- $1 \alpha$ (HIF- $1 \alpha)$ and pyruvate dehydrogenase kinase (PDK) accumulation [20-24]. On the other hand, mitochondrial division has been 
also proved to be coordinated with nuclear division via the cellular process named mitotic fission. Increased mitotic fission in HPV, driven by enhanced fission but repressed fusion, accelerates the cell cycle and increases apoptosis resistance [20-24]. Thus, Warburg metabolisms sustain energy homeostasis through inhibiting oxidative metabolism, which may reduce mitochondrial apoptosis, and lead to uncontrolled cell division. Mitochondrial dynamic and metabolic disorders combine to show the hyper-proliferative and apoptosis-resistant phenotypes in pulmonary artery smooth muscle cells [20-24].

The renin-angiotensin-aldosterone system (RAAS) also plays a key role in endothelial injuries. RAAS is a key regulatory system of electrolyte homeostasis and pulmonary artery status and functions through angiotensin-converting enzyme (ACE)/angiotensin II (Ang II)/Ang II type 1 (AT1) receptor axis and angiotensin-converting enzyme 2 (ACE2)/ angiotensin-1-7 Ang-(1-7)/MAS receptor axis. RAAS dysfunction has been proved to be related to the occurrence and development of acute pulmonary injuries and ARDS and may cause a serious prognosis and even death [25-29]. A large number of studies suggest that ACE2 works as the cellular receptor for SARS-CoV-2 entry [30-32]. Similar to other families of Coronaviridae viruses, the protein interactions between the virus and the membrane-bound ACE2 requires the cleavage of the spike glycoprotein $\mathrm{S}$ into two subunits. After the binding of the S1 receptor-binding domain (RBD) to ACE2, the transmembrane protease/serine subfamily 2 (TMPRSS2) cleaves the S2 subunit and facilitates membrane fusion [30-32]. It has been confirmed that SARS-CoV-2 cell entry results in decline of the ACE2 protein, which converts Ang II into Ang-(1-7). Ang II induces proinflammatory cascades when binding to the AT1 receptor, while Ang-(1-7) generates antiinflammatory effects through the interaction with the MAS receptor. Thus, down-regulation of ACE2 would result in pulmonary injury and vasoconstriction [25-29,33]. Besides these mechanisms, relative ACE2 deficiency may also lead to enhanced and protracted tissues, and vessel exposure to Ang II, which then enhances thrombosis, cell proliferation and recruitment, increases tissue permeability, cytokine production and results in inflammation (Table 1) [33,34].

Table 1. Pulmonary pathological changes in COVID-19.

\begin{tabular}{|c|c|c|}
\hline Injuries & Pathogenic Mechanisms & Refs. \\
\hline Alveolar endothelial injury & $\begin{array}{l}\text { Endothelial barrier disruption induces intrapulmonary shunt, hypoxia, } \\
\text { intravascular coagulation and the release of pro-inflammatory factors. }\end{array}$ & {$[1,5,35]$} \\
\hline $\begin{array}{l}\text { ACE2-decline-induced pulmonary } \\
\text { injury }\end{array}$ & $\begin{array}{l}\text { ACE2 deficiency leads to enhanced and protracted tissues, and vessel exposure } \\
\text { to Ang II, which then enhances thrombosis and cell proliferation, increases } \\
\text { tissue permeability, cytokine production and inflammation. }\end{array}$ & [25-34] \\
\hline $\begin{array}{l}\text { Loss of hypoxic pulmonary } \\
\text { vasoconstriction (HPV) }\end{array}$ & $\begin{array}{l}\text { HPV directs blood perfusion from badly-ventilated to well-ventilated alveoli } \\
\text { to optimize gas exchange. }\end{array}$ & [36-38] \\
\hline $\begin{array}{l}\text { General pulmonary } \\
\text { vasoconstriction }\end{array}$ & Lead to pulmonary hypertension and a risk of right-heart failure subsequently. & [39-41] \\
\hline $\begin{array}{l}\text { Severe ventilation-perfusion } \\
\text { mismatch }\end{array}$ & $\begin{array}{l}\text { Induce hypoxemia in the non-injured fraction or/and cause hyper-perfusion of } \\
\text { the small injured fraction. }\end{array}$ & {$[42,43]$} \\
\hline $\begin{array}{l}\text { Intravascular coagulation and } \\
\text { microthrombi formation }\end{array}$ & Lead to increased wasted ventilation and less efficient carbon dioxide removal. & [44-62] \\
\hline Diffuse alveolar damage (DAD) & Lead to hypoxia at the edematous alveoli. & [63-65] \\
\hline Alveolar edema & $\begin{array}{l}\text { Lead to great decline in oxygen diffusion over the blood-air barrier (hypoxia); } \\
\text { Hypoxia in turn inhibits oedema fluid clearance. }\end{array}$ & {$[5,66]$} \\
\hline $\begin{array}{l}\text { Impaired alveolar surfactant } \\
\text { production }\end{array}$ & Increase alveolar surface tension and hamper alveolar fluid resorption. & {$[67-71]$} \\
\hline
\end{tabular}




\section{Ventilation-Perfusion Mismatch and Intravascular Coagulation in COVID-19}

HPV is thought to optimize gas exchange through shunting blood from poorly ventilated areas to those rich in oxygen. However, a general pulmonary vasoconstriction happens in both normoxic lung competencies and hypoxic lung competencies, which may lead to the pulmonary hypertension $(\mathrm{PH})$ and a risk of right-heart failure subsequently, just as observed in patients with acute altitude sickness $[19,35,36]$. HPV has been observed in COVID-19 patients [37,38]. Moreover, the pulmonary hypertension and the subsequent right ventricular dysfunction also have been confirmed in severe COVID-19 patients (Table 1) [39,40]. Significant alternations in monocyte size, lymphocyte stiffness, neutrophil size and deformability, and heterogeneity of erythrocyte size and deformation in COVID-19 patients also indicated great changes in pulmonary blood stream dynamics [41].

Nevertheless, drugs to inhibit HPV, such as acetazolamide, calcium channel blockers and phosphodiesterase- 5 inhibitors, should be avoided for COVID-19 patients, given that the consequences of COVID-19 may be exacerbated by loss of HPV, whether because of the destructive effects of the virus on mitochondria or the ability of endotoxin and inflammatory stimuli to eliminate HPV [38]. HPV attenuating drugs may exacerbate hypoxemia in COVID-19 pneumonia [38].

In some cases, dysregulated HPV may also cause mismatched blood flow and alveolar ventilation, which may restore the oxygen supply to the poorly-ventilated alveolar cells and result in life-threatening hypoxemia [35]. Recently, Herrmann et al. [42] modeled lung perfusion abnormalities and suggested that early COVID-19 hypoxemia may be mainly attributed to severe ventilation-perfusion mismatch. Their model predicted that calculated shunt fractions in excess of three times the injured fractions, which could be explained by (a) extensive perfusion defect, (b) perfusion defect combined with ventilationperfusion mismatching in the non-injured fraction, or (c) hyper-perfusion of the small injured regions, with up to 3-fold increases in regional perfusion to the afflicted fraction [42]. Clinical features of COVID-19 pneumonia also confirmed the malfunction of oxygensensing responses including the ventilation-perfusion mismatch (Table 1) [43].

Pulmonary intravascular coagulation also plays an important role in the disease progression of COVID-19. After alveolar injuries, resident alveolar macrophages are activated, causing the release of potent proinflammatory mediators and chemokines that promote the accumulation of neutrophils and monocytes, such as vascular endothelial growth factor (VEGF), angiotensin II (Ang II), glycosaminoglycans (GAGs), von Willebrand factor (vWF) and soluble intercellular adhesion molecule (sICAM-1) [5]. Activated neutrophils further contribute to injuries through releasing toxic mediators. On the other hand, intravascular coagulation leads to platelet aggregation and micro-thrombi formation, which may aggravate the pulmonary injuries [5]. Intravascular coagulation primarily leads to increased dead space (increased wasted ventilation and less efficient carbon dioxide removal). Whereas inflammatory mediators from endothelial injury may worsen hypoxemia through exacerbate ventilation-perfusion mismatching (Table 1) [35,44]. Coagulation and thrombosis have been identified clinically as prominent symptoms of COVID-19 [45,46].

Nevertheless, neither intravascular coagulation nor ventilation-perfusion mismatch could be easily corrected. Oxygen supply is a common treatment to COVID-19 patients. Increasing inspired oxygen results in enhanced oxygenation but however does not improve the ratio of arterial oxygen tension to fractional inspired oxygen $\left(P_{\mathrm{a}} \mathrm{O}_{2}: F_{\mathrm{i}} \mathrm{O}_{2}\right)$ [42]. Inhaled nitric oxide decreases total pulmonary vascular resistance $[47,48]$ but however may increase blood flow to these low ventilation-perfusion regions, which causes further arterial desaturation (Table 2) [35]. 
Table 2. Putative drugs and treatments to SARS-CoV-2 pneumonia.

\begin{tabular}{|c|c|c|c|}
\hline Drugs or Treatments & Therapeutic Mechanisms & Therapeutic Effects & Refs. \\
\hline Oxygen inhalation & Oxygenation enhancement & $\begin{array}{l}\text { Alleviate hypoxia; however, high-flow oxygen lead } \\
\text { to pulmonary toxic effects. }\end{array}$ & [35] \\
\hline Mechanical ventilation & Oxygenation enhancement & $\begin{array}{l}\text { Alleviate hypoxia; however, mechanical ventilation } \\
\text { may cause mucus to be blown deep into the small } \\
\text { airways, which then aggravates alveolar hypoxia. }\end{array}$ & [9] \\
\hline ECMO & Oxygenation enhancement & $\begin{array}{l}\text { Alleviate hypoxia; however, patients receiving } \\
\text { ECMO still showed a high mortality rate. }\end{array}$ & [9] \\
\hline Inhaled nitric oxide & $\begin{array}{l}\text { Decrease pulmonary vascular } \\
\text { resistance }\end{array}$ & $\begin{array}{l}\text { Improve ventilation-perfusion ratio; however, may } \\
\text { cause further arterial desaturation (hypoxia). }\end{array}$ & {$[35,47,48]$} \\
\hline Aspirin & Anticoagulation & $\begin{array}{l}\text { Reduce ICU cases, but show no apparent association } \\
\text { with the fatality. }\end{array}$ & [49-51] \\
\hline Heparin & $\begin{array}{l}\text { Anticoagulation; block virus } \\
\text { entry; increase antibody titres }\end{array}$ & $\begin{array}{l}\text { Reduce the risk of in-hospital mortality and decrease } \\
\text { the occurrence of severe cases; however, could not } \\
\text { completely prevent occurrence of severe cases. }\end{array}$ & [52-62] \\
\hline $\begin{array}{l}\text { Exogenous pulmonary } \\
\text { surfactant }\end{array}$ & Alleviate alveolar edema & $\begin{array}{l}\text { Reduce the mortality of infants with neonatal RDS; } \\
\text { however, clinical outcomes for COVID-19 patients } \\
\text { need further investigation. }\end{array}$ & [67-71] \\
\hline $\begin{array}{l}\text { Ethanol-oxygen vapor } \\
\text { therapy }\end{array}$ & Alleviate alveolar edema & $\begin{array}{l}\text { May reduce occurrence of severe cases and the } \\
\text { mortality rate (need clinical verification). }\end{array}$ & [72-75] \\
\hline $\begin{array}{l}\text { Conservative fluid } \\
\text { management }\end{array}$ & Alleviate alveolar edema & $\begin{array}{l}\text { May reduce occurrence of severe cases and the } \\
\text { mortality rate (need clinical verification). }\end{array}$ & {$[76,77]$} \\
\hline
\end{tabular}

Aspirin, the most commonly used anti-platelet agent, is a cyclooxygenase- 1 inhibitor and considered as a mild to moderate inhibitor of platelet function [49,50]. Hereby, aspirin has been suggested for COVID-19 patients [49,50]. Aspirin administration had an association with less mechanical ventilation and reduced ICU cases, but showed no apparent association with the fatality rate (Table 2) [51]. The therapeutic effects of low molecular weight heparin have also been investigated comprehensively [52-58]. Heparin may reduce the risk of in-hospital mortality and decrease the occurrence of severe cases. However, critically-ill COVID-19 patients still had high incidences of venous thromboembolism and worse outcomes, despite the heparin administration at the prophylactic dosage [52-58]. Moreover, besides its anticoagulation effect, heparin relieves the symptoms through complex mechanisms. SARS-CoV rolls onto the cell membrane by binding to cell-surface heparan sulfate proteoglycans (HSPGs) and scans for the specific entry receptor ACE2 [59,60]. In addition, heparin may enhance the open conformation of the subsequent ACE2 binding. Thus, heparin potently blocks both viral adhesion and spike protein binding with the host cell plasma membrane $[59,60]$. On the other hand, an heparin-binding sequence immediately upstream of the S1/S2 cleavage site has been found on SARS-CoV-2 S protein, indicating that heparin may promote the S1/S2 cleavage, induce exposure of the optimal epitope, and therefore accelerate the virus clearance [61]. These assumptions have been proved by a serological study that adding $10 \mu \mathrm{M}$ heparins into the sera from COVID-19 patients led to a four-fold increase in antibody titers [62].

In summary, initial anticoagulant treatments with low-molecular-weight heparin or aspirin may reduce mortality and achieve a significant improvement in $P_{\mathrm{a}} \mathrm{O}_{2}: F_{\mathrm{i}} \mathrm{O}_{2}$ in some patients but however could not completely prevent occurrence of severe cases [49-58].

\section{Alveolar Edema in COVID-19}

Besides above pathogenic mechanisms, alveolar edema also plays a key role in the disease progression. Diffuse alveolar damage (DAD) is the histopathological pattern commonly described in COVID-19 (Table 1) [63-65]. Endothelial barrier disruption induces interstitial flooding via activation of the actin-myosin contractile apparatus [5]. Then 
alveolar edema leads to hypoxia at the injured alveolar units [5]. Hypoxia in turn inhibits edema fluid clearance, due in part to the disassembly of the keratin intermediate filament network, a fundamental element of the cellular cytoskeleton, therefore destructing the epithelial barrier [66]. Therefore, a long-term hypoxia aggravates the disease by inducing more alveolar edema, which forms a vicious circle (Table 1).

Impaired alveolar surfactant production may be another molecular mechanism of alveolar edema in COVID-19 in that the limitation of alveolus superficial active substance would increase alveolar surface tension and hamper alveolar fluid resorption (Table 1) [67-71]. Thus, treatments to alveolar edema may help to both reduce the size of poorly ventilated area and increase the blood oxygen content (Figure 1). Although exogenous surfactant replacements in animal models of ARDS and neonatal respiratory distress syndrome (RDS) showed consistent improvement in gas exchange and survivals, some adult studies have shown only improved oxygenation but no survival benefits [70]. Moreover, a few exogenous pulmonary surfactants have been currently authorized to treat pulmonary permeability edema in COVID-19 patients [70].

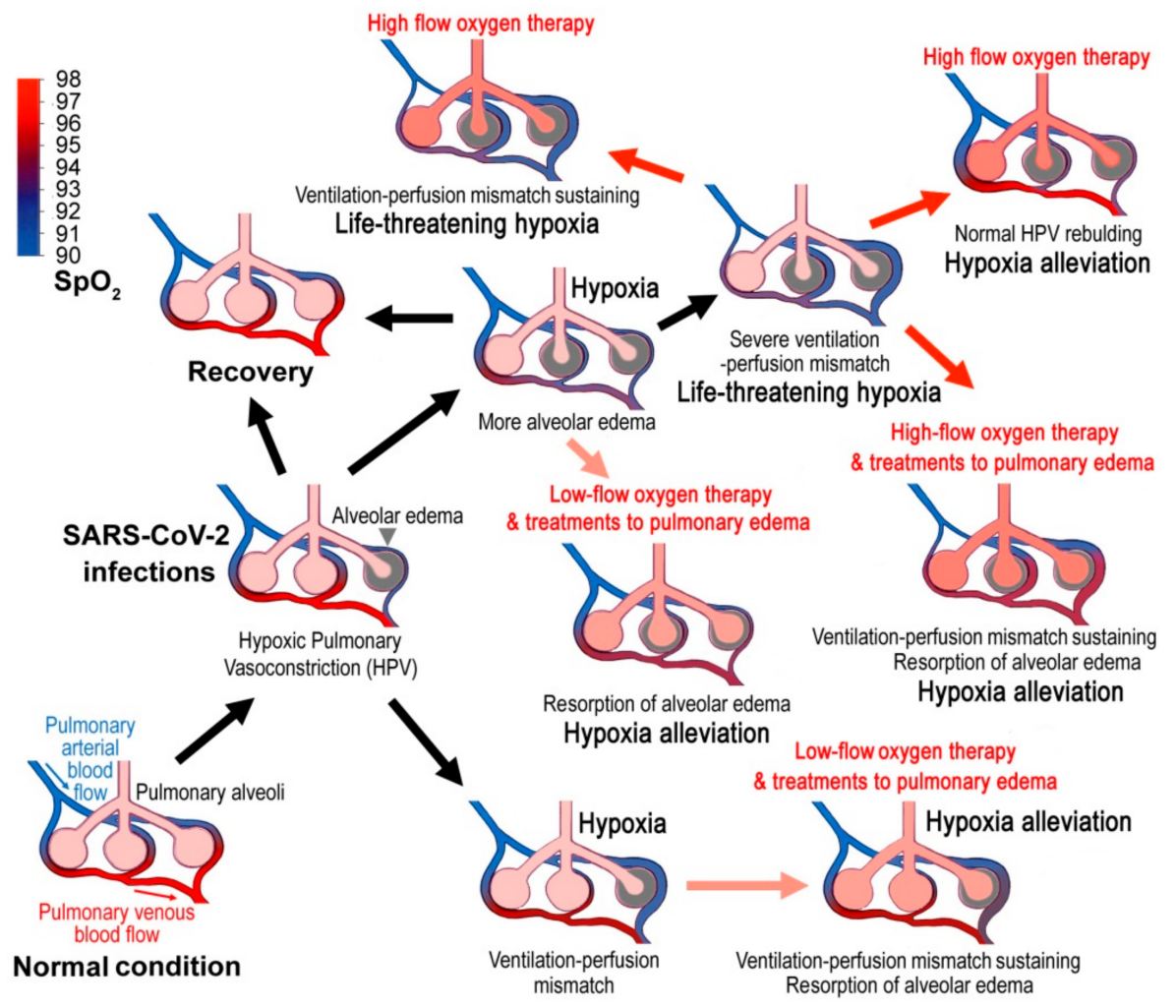

Figure 1. Hypothetically pathogenic mechanisms of COVID-19 and the corresponding therapies. Virus infections cause alveolar edema and the hypoxic pulmonary vasoconstriction (HPV), which is an essential protection mechanism of the lung that directs blood perfusion from badly-ventilated to wellventilated alveoli to optimize gas exchange. However, SARS-CoV-2 infections may cause mismatched blood flow and alveolar ventilation, and may result in life-threatening hypoxemia. Treatments to pulmonary edema might promote lung edema resorption and show good therapeutic effects. When the disease develops into late stages, systemic alveolar edema and severe ventilation-perfusion mismatch occurs, and the blood oxygen will decline sharply. Then the high-flow oxygen therapy will be required. However, high-flow oxygen inhalation may not correct ventilation-perfusion mismatch and cause several adverse effects. The blue to red gradient bar shows blood oxygen saturation $\left(\mathrm{SpO}_{2}\right)$.

Besides exogenous surfactant replacements, other treatments that counter-balance the inhibition of edema clearance during hypoxia or improve the lung's ability to clear alveolar edema should also be adopted. For example, a relatively high partial pressure of $\mathrm{O}_{2}$ in 
the alveolar gas facilitates alveolar fluid resorption by activating $\mathrm{Na}^{+}$transport across the alveolar epithelium, which makes an osmotic gradient responsible for the lung edema clearance [66]. Hereby, appropriate oxygen inhalation would accelerate the resorption of pulmonary edema fluid. However, simple oxygen therapy would not achieve adequate effects on alveolar edema clearance. Ethanol/butanol-oxygen vapor therapy (oxygen inhalation with $20 \%$ ethanol or butanol as humidifying agent) is a common treatment to pulmonary edema with a long history of safety [72-75]. Ethanol/butanol vapor decreases the surface tension of the foam inside the pulmonary alveoli and therefore alleviating alveolar edema (Table 2) [72-75]. Moreover, conservative fluid management, in which diuretics may be administered and intravenous fluid administration is minimized, would reduce hydrostatic pressure and enhance serum oncotic pressure, and therefore limit the development of pulmonary edema potentially (Table 2) [76-78]. Unfortunately, these common therapies to pulmonary edema have not attracted enough attention in COVID-19 clinical practice.

Autopsy showed that pulmonary fibrosis was not serious in dead patients with SARSCoV-2 infections. Intact alveoli could still be seen, but exudation was serious $[64,65,79-82]$, suggesting the severe alveolar edema. COVID-19 has a prominent feature, that is, a large amount of mucus (edema fluid) could be found in the small airway [64,65,79-82], which is distinct from other acute pulmonary injuries.

When the disease develops into late stages, systemic alveolar edema and severe ventilation-perfusion mismatch occur, and the blood oxygen will decline sharply. Then the high flow oxygen therapy and mechanical ventilation will be required (Figure 1). However, high-flow oxygen inhalation inhibits HPV because of the reversed diffusion of oxygen, that is, if enough oxygen could bind the receptor in the small alveolar-capillary-arteriole space, the vessels will not vasoconstrict [83]. Upon a high-flow and high-concentration oxygen inhalation, the reflex stimulation to respiration by hypoxia will disappear, resulting in a more serious retention of $\mathrm{CO}_{2}$, which may lead to the hypercapnic encephalopathy (hypercapnic coma) or even a respiratory arrest [35]. Furthermore, high inspired oxygen concentrations could lead to pulmonary-specific toxic effects, such as denitrogenation phenomena, inhibition of surfactant production and severe acidosis, and therefore may worsen ventilation-perfusion mismatch or induce a degree of hypoventilation (Table 2) [84,85]. On the other hand, mechanical ventilation may cause mucus to be blown into the deep of the small airways, which then aggravates intrapulmonary shunt and alveolar hypoxia (Table 2) [86]. These deleterious effects may be an important reason for the high mortality after high-flow oxygen inhalation and mechanical ventilation (The ICU mortality rate among those who required non-invasive ventilation was $79 \%$ and among those who required invasive mechanical ventilation was $86 \%$.) [9]. Therefore, nebulized heparin treatments, ethanol-oxygen vapor therapy should be given at the early stages of COVID-19.

\section{The Optimal Time and $\mathrm{SpO}_{2}$ Threshold for Oxygen Therapy}

In a retrospective case report that included 69 adults in Wuhan, China, 29\% of patients showed dyspnea and $20 \%$ of cases (14 patients) showed oxygen saturation $\mathrm{SpO}_{2}<90 \%$ [oxygen index $(\mathrm{OI})<110 \mathrm{mmHg}$ ] during admission [87]. In their report, as of 4 February 2020, $18(26.9 \%)$ of 67 patients had been discharged, and five patients had died, with a mortality rate of $7.5 \%$. Noticeably, all five deaths occurred in the $\mathrm{SpO}_{2}<90 \%$ group [87]. The median time from onset of symptoms to admission was six days (inter quartile range $4-9$ days). However in the $\mathrm{SpO}_{2}<90 \%$ group, the median occurrence time of lowest $\mathrm{SpO}_{2}$ was only one day (inter quartile range 0-2 days) after admission [87]. In other words, $\mathrm{SpO}_{2}$ of some patients at admission were already very low, which may develop severe ARDS subsequently (Table 3). Therefore, it may be too late for the patients to take oxygen therapy after admission. The best window period of oxygen therapy may be the six days from onset of symptoms to admission.

Dai et al. [88] classified COVID-19 patients into four stages according to the CT (Computed tomography, which uses X-rays to produce cross-sectional images) performances. 
Stage I: one or more lesions, in irregularly patchy or round shapes, generally showing ground-glass opacity with vascular enlargements. Stage II: more area lesions, found in bilateral lobes mainly at the sub-pleural areas, in irregularly patchy, round or reverse-butterfly shapes, diffused or scattered patches occasionally fusing into a large patch with a high density, vascular enlargements, reticular signs and bronchial wall thickening, sometimes with little fibrosis and atelectasis in sub-segments. Stage III: some lesions diminished or absorbed, the focus could be entirely absorbed, showing residual fibers. Stage IV: bilateral diffuse inhibitions, over half of the lung areas involved, occasionally extended to the entire lung and defined as the white lung, implying the systemic alveolar edema. However, the patients in the stage IV group showed only slightly-declined $\mathrm{SpO}_{2}(94.70 \pm 0.20 \%)$. While the stage II patients with only a small proportion of lung injury and HPV showed relatively high $\mathrm{SpO}_{2}\left(97.2 \pm 0.91 \%\right.$ ) [88]. $\mathrm{SpO}_{2}<95 \%$ may indicate late infection stages (Table 3) [88].

Moreover, a recent study demonstrated a high correlation between decreased $\mathrm{SpO}_{2}$ and severe cases that $78.0 \%(32 / 41)$ of the patients with $\mathrm{SpO}_{2} \leq 95 \%$ would develop into severe diseases (Table 3) [89]. The risk threshold of $\mathrm{SpO}_{2}$ was 95\%.

WHO and BMJ Best Practice suggested $\mathrm{SpO}_{2} \leq 90 \%$ or signs of severe respiratory distress, central cyanosis, shock, coma and/or convulsions as diagnostic standards for the severe pulmonary infections $[90,91]$. In addition, according to the novel coronavirus pneumonia diagnosis and treatment plan (trial version 7) published by the National Health Committee of China, either respiratory rate $(R R) \geq 30$ times per minute, or resting state $\mathrm{SpO}_{2} \leq 93 \%$, or OI $\leq 300 \mathrm{mmHg}$ was defined as the severe condition, and then the oxygen therapy was given (Table 3) [92]. However, the median $\mathrm{SpO}_{2} /$ respiratory rate value was significantly higher in COVID-19 patients than in non-COVID-19 patients, which implies that a normal breathing rate could mask profound hypoxia and make severity assessment in COVID-19 patients more difficult in out-of-hospital settings [93]. Besides, based on the above analysis, the diagnostic standard of $\mathrm{SpO}_{2}$ either $\leq 90 \%$ or $\leq 93 \%$ may be too low to take the oxygen therapy in time.

Table 3. Blood oxygen saturation $\left(\mathrm{SpO}_{2}\right)$ lower limit and upper limit for oxygen therapy.

\begin{tabular}{|c|c|c|c|}
\hline $\mathrm{SpO}_{2}$ Limi & & Corresponding Disease Stage & Refs. \\
\hline \multirow{4}{*}{$\begin{array}{c}\mathrm{SpO}_{2} \text { Lower } \\
\text { Limit for } \\
\text { Oxygen Therapy }\end{array}$} & $90 \%$ & $\begin{array}{c}\text { In the } \mathrm{SpO}_{2}<90 \% \text { group, the median occurrence time of lowest } \mathrm{SpO}_{2} \text { was only one day } \\
\text { after admission, indicating a very late stage. }\end{array}$ & [87] \\
\hline & $94.7 \%$ & $\begin{array}{l}\text { Stage IV: bilateral diffuse inhibitions, over half of the lung areas involved, occasionally } \\
\text { extended to the entire lung and defined as the white lung. }\end{array}$ & [88] \\
\hline & $95 \%$ & $78.0 \%$ of the patients with $\mathrm{SpO}_{2} \leq 95 \%$ would develop into severe diseases (late stages). & [89] \\
\hline & $93 \%$ & Resting state $\mathrm{SpO}_{2} \leq 93 \%$ indicates a severe condition (late stages). & [92] \\
\hline $\mathrm{SpO}_{2}$ Upper & $96 \%$ & For most patients receiving oxygen therapy. & {$[94,95]$} \\
\hline Limit for & $88-92 \%$ & For patients at risk of hypercapnic respiratory failure. & [94] \\
\hline Oxygen Therapy & $88-92 \%$ & For patients with chronic type II respiratory failure. & [92] \\
\hline
\end{tabular}

\section{Four Clinical Comments}

Based on the above analysis, we propose four comments to prevent SARS-CoV-2 patients from developing into severe hypoxemia:

(a) For the suspected cases with symptoms, finger $\mathrm{SpO}_{2}$ (with finger oximeter ideally) should be measured at each time of nucleic acid test sampling and daily after symptom onset. However, finger $\mathrm{SpO}_{2}$ varies greatly with the altitude and the age [35], and the finger oximeter itself may have a large deviation, so it is recommended that each oximeter should be calibrated with several healthy people of different ages to get the reference value. If the patient's $\mathrm{SpO}_{2}$ was lower than the reference value by $3 \%$ or more (e.g., if the reference value was $98 \%$, then $\leq 95 \%$ is the threshold for oxygen therapy), it is suggested that the patients were hospitalized immediately for standard low-flow oxygen inhalation possibly combined with $20 \%$ ethanol as humidifier. If immediate hospitalization was not possible, the patient was recommended to take oxygen in the 
home, such as with a portable oxygen respirator. During the in-home oxygen therapy, finger $\mathrm{SpO}_{2}$ should be monitored continually to assure that $\mathrm{SpO}_{2}$ has been restored to $96 \%$, but not higher than that (Table 3). This is because saturation above this level likely causes an increased risk of death without plausible benefits [94,95]. This upper limit may be lower for the patients with chronic respiratory diseases. For instance, the oxygen treatment goal should be $88-92 \%$ for patients with chronic type II respiratory failure (Table 3) [92]. Nevertheless, if $\mathrm{SpO}_{2}$ cannot be enhanced afterwards, the patient should seek medical advice or go to the hospital in time. The in-home oxygen therapy may be of great significance for countries with a shortage of medical resources. The COVID-19 patients usually require oxygen long-term oxygen supplies. However, if humidification with $20 \%$ ethanol was adopted, long-time ethanol vapor inhalation may generate adverse effects to the respiratory system and the nervous system $[96,97]$. The optimal length of ethanol-oxygen vapor therapy needs to be investigated in clinical trials.

(b) For the patients with very low $\mathrm{SpO}_{2}$, high-flow oxygen inhalation should be applied. Nevertheless, humidification with $20 \%$ ethanol might be also recommended on this occasion.

(c) Fluid management might be considered for all COVID-19 patients and conservative fluid management might be applied to severe cases. Some patients may be dehydrated with evolving acute kidney injury at hospital presentation for COVID-19 pneumonia. Therefore, conservative fluid management to these patients should be applied with caution. Detailed guidance of fluid administration in patients with COVID-19 has been discussed elsewhere [98]. For the in-home patients, appropriate reduction in water intake might be an expedient measure.

(d) The prone position could reduce the risk of ventilation-associated lung injuries by the combined effects of more uniform distribution of breathing and less compression of the left lower pulmonary lobe by the heart [5,99-101]. Therefore, patients with low $\mathrm{SpO}_{2}$ are advised to use prone position as much as possible. In addition, the patients should avoid any vigorous activity that may increase respiratory rate and tidal volume because pulmonary injury will be worsened by the mechanical stretch during the strained breathing [5,99-101]. The benefit of prone ventilation is larger than that for typical ARDS. HPV is regionally variable, resulting in heterogenous ventilationperfusion matching. Prone ventilation may minimize the heterogeneity and allow HPV to divert blood flow to the caudal/dorsal regions of the lung. Although HPV is considered to be weak in COVID-19, residual HPV might be optimized when prone [38].

\section{Clinical Outlook}

In summary, we suggest that in the beginning of the COVID-19 pulmonary involvement (decrease of $\mathrm{SpO}_{2}$ of $3 \%$ ) the patients should receive immediate oxygen therapy and pulmonary edema treatments. However, this is merely a concept paper that needs to be tested in controlled randomized trials. It should be noted that not only $\mathrm{SpO}_{2}$ is important but also the patient's associated tachypnea or hyperpnea, and $\mathrm{SpO}_{2}$ should be interpreted with caution as there is a left-sided shifting of the oxyhemoglobin dissociation curve due to tachypnea/hyperpnea induced by hypoxemia [102]. Thus, $\mathrm{SpO}_{2}$ monitoring with a finger oximeter is just a stop-gap measure, and the CT performance is still a "golden rule".

Besides ventilation-perfusion mismatch, intravascular coagulation and alveolar edema, COVID-19 ARDS is a very complex disease, with intrapulmonary shunting, impaired lung diffusion, inflammation, etc. [103-109]. We cannot expect that early oxygen therapy and pulmonary edema treatments can prevent every COVID-19 patient from the development of ARDS. Antiviral drugs, anti-inflammatory agents and anticoagulant therapies (e.g., heparin as mentioned above) should be adopted along with pulmonary edema treatments. 
Author Contributions: Conceptualization, S.Y.; writing-original draft preparation, S.Y., S.-C.J. and Z.-W.Z.; writing-review and editing, Y.-F.F., J.H. and Z.-L.L. All authors have read and agreed to the published version of the manuscript.

Funding: This work was supported by the Project of Sichuan Province Youth Science and Technology Innovation Team (20CXTD0062) to S.Y. and the Applied Basic Research Program of Sichuan Province (20YYJC4388) to Z.-W.Z.

Institutional Review Board Statement: Not applicable.

Informed Consent Statement: Not applicable.

Data Availability Statement: Not applicable.

Conflicts of Interest: Si-Cong Jiang was employed by the Chengdu Kang Hong Pharmaceutical Group Comp. Ltd. The remaining authors declare that the research was conducted in the absence of any commercial or financial relationships that could be construed as a potential conflict of interest.

\section{Abbreviations}

\begin{tabular}{|c|c|}
\hline ACE2 & angiotensin-converting enzyme 2 \\
\hline AEI & alveolar epithelial cells type I \\
\hline AEII & alveolar epithelial cells type II \\
\hline ALI & acute lung injury \\
\hline Ang II & angiotensin II \\
\hline ARDS & acute respiratory distress syndrome \\
\hline COPD & chronic obstructive pulmonary disease \\
\hline COVID-19 & coronavirus disease 2019 \\
\hline $\mathrm{CT}$ & computed tomography \\
\hline DAD & diffuse alveolar damage \\
\hline ECMO & extracorporeal membrane oxygenation \\
\hline$F_{\mathrm{i}} \mathrm{O}_{2}$ & fractional inspired oxygen \\
\hline GAGs & glycosaminoglycans \\
\hline $\mathrm{HIF}-1 \alpha$ & hypoxia inducible factor- $1 \alpha$ \\
\hline $\mathrm{HPV}$ & hypoxic pulmonary vasoconstriction \\
\hline ICU & intensive care unit \\
\hline IPF & idiopathic pulmonary fibrosis \\
\hline $\mathrm{NO}$ & nitric oxide \\
\hline$P_{\mathrm{a}} \mathrm{O}_{2}$ & arterial oxygen tension \\
\hline PASMC & pulmonary artery smooth muscle cells \\
\hline PDK & pyruvate dehydrogenase kinase \\
\hline $\mathrm{PH}$ & pulmonary hypertension \\
\hline PKC & protein kinase $\mathrm{C}$ \\
\hline RAAS & renin-angiotensin-aldosterone system \\
\hline RBD & receptor-binding domain \\
\hline ROS & reactive oxygen species \\
\hline SARS-CoV-2 & SARS-like coronavirus 2 \\
\hline Sicam & soluble intercellular adhesion molecule \\
\hline $\mathrm{SpO}_{2}$ & blood oxygen saturation \\
\hline TMPRSS2 & trans-membrane protease/serine subfamily 2 \\
\hline VEGF & vascular endothelial growth factor \\
\hline vWF & von Willebrand factor \\
\hline
\end{tabular}

\section{References}

1. Huang, C.; Wang, Y.; Li, X.; Ren, L.; Zhao, J.; Hu, Y.; Zhang, L.; Fan, G.; Xu, J.; Gu, X.; et al. Clinical features of patients infected with 2019 novel coronavirus in Wuhan, China. Lancet 2020, 395, 497-506. [CrossRef]

2. Chen, N.; Zhou, M.; Dong, X.; Qu, J.; Gong, F.; Han, Y.; Qiu, Y.; Wang, J.; Liu, Y.; Wei, Y.; et al. Epidemiological and clinical characteristics of 99 cases of 2019 novel coronavirus pneumonia in Wuhan, China: A descriptive study. Lancet 2020, 395, 507-513. [CrossRef] 
3. Wölfel, R.; Corman, V.M.; Guggemos, W.; Seilmaier, M.; Zange, S.; Müller, M.A.; Niemeyer, D.; Jones, T.C.; Vollmar, P.; Rothe, C.; et al. Virological assessment of hospitalized patients with COVID-2019. Nature 2020, 581, 465-469. [CrossRef]

4. Fan, E.; Beitler, J.R.; Brochard, L.; Calfee, C.S.; Ferguson, N.D.; Slutsky, A.S.; Brodie, D. COVID-19-associated acute respiratory distress syndrome: Is a different approach to management warranted? Lancet Respir. Med. 2020, 8, 816-821. [CrossRef]

5. Thompson, B.T.; Chambers, R.C.; Liu, K.D. Acute respiratory distress syndrome. N. Engl. J. Med. 2017, 377, 562-572. [CrossRef]

6. Meduri, G.U.; Annane, D.; Confalonieri, M.; Chrousos, G.P.; Rochwerg, B.; Busby, A.; Ruaro, B.; Meibohm, B. Pharmacological principles guiding prolonged glucocorticoid treatment in ARDS. Intensiv. Care Med. 2020, 46, 2284-2296. [CrossRef] [PubMed]

7. Guan, W.J.; Ni, Z.Y.; Hu, Y.; Liang, W.H.; Ou, C.Q.; He, J.X.; Liu, L.; Shan, H.; Lei, C.L.; Hui, D.S.C.; et al. Clinical characteristics of coronavirus disease 2019 in China. N. Engl. J. Med. 2020, 382, 1708-1720. [CrossRef] [PubMed]

8. Gattinoni, L.; Coppola, S.; Cressoni, M.; Busana, M.; Rossi, S.; Chiumello, D. COVID-19 does not lead to a "typical" Acute Respiratory Distress Syndrome. Am. J. Respir. Crit. Care Med. 2020, 201, 1299-1300. [CrossRef] [PubMed]

9. Yang, X.; Yu, Y.; Xu, J.; Shu, H.; Xia, J.; Liu, H.; Wu, Y.; Zhang, L.; Yu, Z.; Fang, M.; et al. Clinical course and outcomes of critically ill patients with SARS-CoV-2 pneumonia in Wuhan, China: A single-centered, retrospective, observational study. Lancet Respir. Med. 2020, 8, 475-481. [CrossRef]

10. Ruaro, B.; Salton, F.; Braga, L.; Wade, B.; Confalonieri, P.; Volpe, M.C.; Baratella, E.; Maiocchi, S.; Confalonieri, M. The history and mystery of alveolar epithelial type II cells: Focus on their physiologic and pathologic role in lung. Int. J. Mol. Sci. 2021, $22,2566$. [CrossRef]

11. Geri, P.; Salton, F.; Zuccatosta, L.; Tamburrini, M.; Biolo, M.; Busca, A.; Santagiuliana, M.; Zuccon, U.; Confalonieri, P.; Ruaro, B.; et al. Limited role for bronchoalveolar lavage to exclude COVID-19 after negative upper respiratory tract swabs: A multicentre study. Eur. Respir. J. 2020, 56, 2001733. [CrossRef]

12. Morris, G.; Bortolasci, C.C.; Puri, B.K.; Olive, L.; Marx, W.; O’Neil, A.; Athan, E.; Carvalho, A.F.; Maes, M.; Walder, K.; et al. The pathophysiology of SARS-CoV-2: A suggested model and therapeutic approach. Life Sci. 2020, 258, 118166. [CrossRef]

13. Chilosi, M.; Poletti, V.; Ravaglia, C.; Rossi, G.; Dubini, A.; Piciucchi, S.; Pedica, F.; Bronte, V.; Pizzolo, G.; Martignoni, G.; et al. The pathogenic role of epithelial and endothelial cells in early-phase COVID-19 pneumonia: Victims and partners in crime. Mod. Pathol. 2021. [CrossRef] [PubMed]

14. Pannone, G.; Caponio, V.C.A.; De Stefano, I.S.; Ramunno, M.A.; Meccariello, M.; Agostinone, A.; Pedicillo, M.C.; Troiano, G.; Zhurakivska, K.; Cassano, T.; et al. Lung histopathological findings in COVID-19 disease-A systematic review. Infect. Agent Cancer 2021, 16, 34. [CrossRef]

15. Salton, F.; Confalonieri, P.; Meduri, G.U.; Santus, P.; Harari, S.; Scala, R.; Lanini, S.; Vertui, V.; Oggionni, T.; Caminati, A.; et al. Prolonged low-dose methylprednisolone in patients with severe COVID-19 pneumonia. Open Forum Infect. Dis. 2020, 7, ofaa421. [CrossRef] [PubMed]

16. Dada, L.A.; Sznajder, J.I. Hypoxic inhibition of alveolar fluid reabsorption. Adv. Exp. Med. Biol. 2007, 618, 159-168. [CrossRef]

17. Archer, S.L.; Weir, E.K.; Reeve, H.L.; Michelakis, E. Molecular identification of $\mathrm{O}_{2}$ sensors and $\mathrm{O}_{2}$-sensitive potassium channels in the pulmonary circulation. Adv. Exp. Med. Biol. 2000, 475, 219-240. [CrossRef]

18. Yuan, S. Drugs to cure avian influenza infection-Multiple ways to prevent cell death. Cell Death Dis. 2013, 4, e835. [CrossRef]

19. Kylhammar, D.; Rådegran, G. The principal pathways involved in the in vivo modulation of hypoxic pulmonary vasoconstriction, pulmonary arterial remodelling and pulmonary hypertension. Acta Physiol. 2017, 219, 728-756. [CrossRef] [PubMed]

20. Sommer, N.; Strielkov, I.; Pak, O.; Weissmann, N. Oxygen sensing and signal transduction in hypoxic pulmonary vasoconstriction. Eur. Respir. J. 2016, 47, 288-303. [CrossRef]

21. Dunham-Snary, K.J.; Wu, D.; Sykes, E.A.; Thakrar, A.; Parlow, L.R.G.; Mewburn, J.D.; Parlow, J.L.; Archer, S.L. Hypoxic pulmonary vasoconstriction: From molecular mechanisms to medicine. Chest 2017, 151, 181-192. [CrossRef]

22. Villamor, E.; Moreno, L.; Mohammed, R.; Pérez-Vizcaíno, F.; Cogolludo, A. Reactive oxygen species as mediators of oxygen signaling during fetal-to-neonatal circulatory transition. Free Radic. Biol. Med. 2019, 142, 82-96. [CrossRef] [PubMed]

23. Dasgupta, A.; Wu, D.; Tian, L.; Xiong, P.Y.; Dunham-Snary, K.J.; Chen, K.H.; Alizadeh, E.; Motamed, M.; Potus, F.; Hindmarch, C.C.T.; et al. Mitochondria in the pulmonary vasculature in health and disease: Oxygen-sensing, metabolism, and dynamics. Compr. Physiol. 2020, 10, 713-765. [CrossRef]

24. Sommer, N.; Alebrahimdehkordi, N.; Pak, O.; Knoepp, F.; Strielkov, I.; Scheibe, S.; Dufour, E.; Andjelković, A.; Sydykov, A.; Saraji, A.; et al. Bypassing mitochondrial complex III using alternative oxidase inhibits acute pulmonary oxygen sensing. Sci. Adv. 2020, 6, eaba0694. [CrossRef] [PubMed]

25. Kreutz, R.; Algharably, E.A.E.; Azizi, M.; Dobrowolski, P.; Guzik, T.; Januszewicz, A.; Persu, A.; Prejbisz, A.; Riemer, T.G.; Wang, J.G.; et al. Hypertension, the renin-angiotensin system, and the risk of lower respiratory tract infections and lung injury: Implications for COVID-19. Cardiovasc. Res. 2020, 116, 1688-1699. [CrossRef] [PubMed]

26. Kai, H.; Kai, M. Interactions of coronaviruses with ACE2, angiotensin II, and RAS inhibitors-lessons from available evidence and insights into COVID-19. Hypertens. Res. 2020, 43, 648-654. [CrossRef]

27. Hussman, J.P. Cellular and molecular pathways of COVID-19 and potential points of therapeutic intervention. Front. Pharmacol. 2020, 11, 1169. [CrossRef]

28. Gao, Y.L.; Du, Y.; Zhang, C.; Cheng, C.; Yang, H.Y.; Jin, Y.F.; Duan, G.C.; Chen, S.Y. Role of renin-angiotensin system in acute lung injury caused by viral infection. Infect. Drug Resist. 2020, 13, 3715-3725. [CrossRef] 
29. Cai, L.; Guo, X.; Cao, Y.; Ying, P.; Hong, L.; Zhang, Y.; Yi, G.; Fu, M. Determining available strategies for prevention and therapy: Exploring COVID-19 from the perspective of ACE2 (Review). Int. J. Mol. Med. 2021, 47, 43. [CrossRef]

30. Yan, R.; Zhang, Y.; Li, Y.; Xia, L.; Guo, Y.; Zhou, Q. Structural basis for the recognition of SARS-CoV-2 by full-length human ACE2. Science 2020, 367, 1444-1448. [CrossRef]

31. Lan, J.; Ge, J.; Yu, J.; Shan, S.; Zhou, H.; Fan, S.; Zhang, Q.; Shi, X.; Wang, Q.; Zhang, L.; et al. Structure of the SARS-CoV-2 spike receptor-binding domain bound to the ACE2 receptor. Nature 2020, 581, 215-220. [CrossRef]

32. Wang, Q.; Zhang, Y.; Wu, L.; Niu, S.; Song, C.; Zhang, Z.; Lu, G.; Qiao, C.; Hu, Y.; Yuen, K.Y.; et al. Structural and functional basis of SARS-CoV-2 entry by using human ACE2. Cell 2020, 181, 894-904.e9. [CrossRef]

33. Costa, L.B.; Perez, L.G.; Palmeira, V.A.; Macedo, E.; e Cordeiro, T.M.; Ribeiro, V.T.; Lanza, K.; e Silva, A.C.S. Insights on SARS-CoV-2 molecular interactions with the renin-angiotensin system. Front. Cell. Dev. Biol. 2020, 8, 559841. [CrossRef]

34. Gan, R.; Rosoman, N.P.; Henshaw, D.J.E.; Noble, E.P.; Georgius, P.; Sommerfeld, N. COVID-19 as a viral functional ACE2 deficiency disorder with ACE2 related multi-organ disease. Med. Hypotheses 2020, 144, 110024. [CrossRef]

35. Petersson, J.; Glenny, R.W. Gas exchange and ventilation-perfusion relationships in the lung. Eur. Respir. J. 2014, 44, 1023-1041. [CrossRef] [PubMed]

36. Yanamandra, U.; Nair, V.; Singh, S. Managing high-altitude pulmonary edema with oxygen alone: Results of a randomized controlled trial. High Alt. Med. Biol. 2016, 17, 294-299. [CrossRef]

37. Rello, J.; Storti, E.; Belliato, M.; Serrano, R. Clinical phenotypes of SARS-CoV-2: Implications for clinicians and researchers. Eur. Respir. J. 2020, 55, 2001028. [CrossRef] [PubMed]

38. Archer, S.L.; Sharp, W.W.; Weir, E.K. Differentiating COVID-19 pneumonia from acute respiratory distress syndrome and high altitude pulmonary edema: Therapeutic implications. Circulation 2020, 142, 101-104. [CrossRef] [PubMed]

39. Pagnesi, M.; Baldetti, L.; Beneduce, A.; Calvo, F.; Gramegna, M.; Pazzanese, V.; Ingallina, G.; Napolano, A.; Finazzi, R.; Ruggeri, A.; et al. Pulmonary hypertension and right ventricular involvement in hospitalised patients with COVID-19. Heart 2020, 106, 1324-1331. [CrossRef]

40. Van Dongen, C.M.; Janssen, M.T.; van der Horst, R.P.; van Kraaij, D.J.; Peeters, R.H.; van den Toorn, L.M.; Mostard, R.L. Unusually rapid development of pulmonary hypertension and right ventricular failure after COVID-19 pneumonia. Eur. J. Case Rep. Intern. Med. 2020, 7, 001784. [CrossRef]

41. Kubánková, M.; Hohberger, B.; Hoffmanns, J.; Fürst, J.; Herrmann, M.; Guck, J.; Kräter, M. Physical phenotype of blood cells is altered in COVID-19. Biophys. J. 2021. [CrossRef]

42. Herrmann, J.; Mori, V.; Bates, J.H.T.; Suki, B. Modeling lung perfusion abnormalities to explain early COVID-19 hypoxemia. Nat. Commun. 2020, 11, 4883. [CrossRef]

43. Mauri, T.; Spinelli, E.; Scotti, E.; Colussi, G.; Basile, M.C.; Crotti, S.; Tubiolo, D.; Tagliabue, P.; Zanella, A.; Grasselli, G.; et al. Potential for lung recruitment and ventilation-perfusion mismatch in patients with the acute respiratory distress syndrome from coronavirus disease 2019. Crit. Care Med. 2020, 48, 1129-1134. [CrossRef]

44. Ospina-Tascón, G.A.; Bautista, D.F.; Madriñán, H.J.; Valencia, J.D.; Bermúdez, W.F.; Quiñones, E.; Calderón-Tapia, L.E.; Hernandez, G.; Bruhn, A.; De Backer, D. Microcirculatory dysfunction and dead-space ventilation in early ARDS: A hypothesis-generating observational study. Ann. Intensiv. Care 2020, 10, 35. [CrossRef] [PubMed]

45. Ackermann, M.; Verleden, S.E.; Kuehnel, M.; Haverich, A.; Welte, T.; Laenger, F.; Vanstapel, A.; Werlein, C.; Stark, H.; Tzankov, A.; et al. Pulmonary vascular endothelialitis, thrombosis, and angiogenesis in COVID-19. N. Engl. J. Med. 2020, 383, 120-128. [CrossRef] [PubMed]

46. Gómez-Mesa, J.E.; Galindo-Coral, S.; Montes, M.C.; Muñoz Martin, A.J. Thrombosis and coagulopathy in COVID-19. Curr. Probl. Cardiol. 2021, 46, 100742. [CrossRef] [PubMed]

47. Adusumilli, N.C.; Zhang, D.; Friedman, J.M.; Friedman, A.J. Harnessing nitric oxide for preventing, limiting and treating the severe pulmonary consequences of COVID-19. Nitric Oxide 2020, 103, 4-8. [CrossRef]

48. Ricciardolo, F.L.M.; Bertolini, F.; Carriero, V.; Högman, M. Nitric oxide's physiologic effects and potential as a therapeutic agent against COVID-19. J. Breath Res. 2020, 15, 014001. [CrossRef]

49. Mohamed-Hussein, A.A.R.; Aly, K.M.E.; Ibrahim, M.A.A. Should aspirin be used for prophylaxis of COVID-19-induced coagulopathy? Med. Hypotheses 2020, 144, 109975. [CrossRef] [PubMed]

50. Haque, S.; Jawed, A.; Akhter, N.; Dar, S.A.; Khan, F.; Mandal, R.K.; Areeshi, M.Y.; Lohani, M.; Wahid, M. Acetylsalicylic acid (Aspirin): A potent medicine for preventing COVID-19 deaths caused by thrombosis and pulmonary embolism. Eur. Rev. Med. Pharmacol. Sci. 2020, 24, 9244-9245. [CrossRef] [PubMed]

51. Chow, J.H.; Khanna, A.K.; Kethireddy, S.; Yamane, D.; Levine, A.; Jackson, A.M.; McCurdy, M.T.; Tabatabai, A.; Kumar, G.; Park, P.; et al. Aspirin use is associated with decreased mechanical ventilation, ICU admission, and in-hospital mortality in hospitalized patients with COVID-19. Anesth. Analg. 2021, 132, 930-941. [CrossRef] [PubMed]

52. Pavoni, V.; Gianesello, L.; Pazzi, M.; Stera, C.; Meconi, T.; Frigieri, F.C. Venous thromboembolism and bleeding in critically ill COVID-19 patients treated with higher than standard low molecular weight heparin doses and aspirin: A call to action. Thromb. Res. 2020, 196, 313-317. [CrossRef] [PubMed]

53. Falcone, M.; Tiseo, G.; Barbieri, G.; Galfo, V.; Russo, A.; Virdis, A.; Forfori, F.; Corradi, F.; Guarracino, F.; Carrozzi, L.; et al. Role of low-molecular-weight heparin in hospitalized patients with severe acute respiratory syndrome coronavirus 2 pneumonia: A prospective observational sudy. Open Forum Infect. Dis. 2020, 7, ofaa563. [CrossRef] [PubMed] 
54. Martinelli, I.; Ciavarella, A.; Abbattista, M.; Aliberti, S.; De Zan, V.; Folli, C.; Panigada, M.; Gori, A.; Artoni, A.; Ierardi, A.M.; et al. Increasing dosages of low-molecular-weight heparin in hospitalized patients with COVID-19. Intern. Emerg. Med. 2021. [CrossRef]

55. Shen, L.; Qiu, L.; Liu, D.; Wang, L.; Huang, H.; Ge, H.; Xiao, Y.; Liu, Y.; Jin, J.; Liu, X.; et al. The association of low molecular weight heparin use and in-hospital mortality among patients hospitalized with COVID-19. Cardiovasc. Drugs Ther. 2021. [CrossRef]

56. Di Castelnuovo, A.; Costanzo, S.; Antinori, A.; Berselli, N.; Blandi, L.; Bonaccio, M.; Cauda, R.; Guaraldi, G.; Menicanti, L.; Mennuni, M.; et al. Heparin in COVID-19 patients is associated with reduced in-hospital mortality: The multicenter Italian CORIST study. Thromb. Haemost. 2021. [CrossRef]

57. Cuker, A.; Tseng, E.K.; Nieuwlaat, R.; Angchaisuksiri, P.; Blair, C.; Dane, K.; Davila, J.; DeSancho, M.T.; Diuguid, D.; Griffin, D.O.; et al. American Society of Hematology 2021 guidelines on the use of anticoagulation for thromboprophylaxis in patients with COVID-19. Blood Adv. 2021, 5, 872-888. [CrossRef]

58. Mennuni, M.G.; Renda, G.; Grisafi, L.; Rognoni, A.; Colombo, C.; Lio, V.; Foglietta, M.; Petrilli, I.; Pirisi, M.; Spinoni, E.; et al. Clinical outcome with different doses of low-molecular-weight heparin in patients hospitalized for COVID-19. J. Thromb. Thrombolysis 2021. [CrossRef]

59. Lang, J.; Yang, N.; Deng, J.; Liu, K.; Yang, P.; Zhang, G.; Jiang, C. Inhibition of SARS pseudovirus cell entry by lactoferrin binding to heparan sulfate proteoglycans. PLoS ONE 2011, 6, e23710. [CrossRef]

60. Clausen, T.M.; Sandoval, D.R.; Spliid, C.B.; Pihl, J.; Perrett, H.R.; Painter, C.D.; Narayanan, A.; Majowicz, S.A.; Kwong, E.M.; McVicar, R.N.; et al. SARS-CoV-2 infection depends on cellular heparan sulfate and ACE2. Cell 2020, 183, 1043-1057.e15. [CrossRef]

61. Yuan, S.; Jiang, S.; Zhang, Z.; Li, Z.; Wang, C.; Yuan, M.; Chen, Y.; Tao, Q.; Lan, T.; Tang, X.; et al. TMPRSS2 protease inhibitors may prolong but heparins accelerate SARS-CoV-2 clearance. Preprints 2020, 2020060249. [CrossRef]

62. Perera, R.A.; Mok, C.K.; Tsang, O.T.; Lv, H.; Ko, R.L.; Wu, N.C.; Yuan, M.; Leung, W.S.; Chan, J.M.; Chik, T.S.; et al. Serological assays for severe acute respiratory syndrome coronavirus 2 (SARS-CoV-2), March 2020. Eurosurveillance 2020, $25,2000421$. [CrossRef] [PubMed]

63. Montero-Fernández, M.A.; Pardo-Garcia, R. Histopathology features of the lung in COVID-19 patients. Diagn. Histopathol. 2021, 27, 123-127. [CrossRef]

64. Takahashi, K.; Kajiura, K.; Nasu, M.; Nakamura, K.; Sugata, K.; Matsuzaki, A. Post-mortem biopsy of a patient with late exacerbation of COVID-19 pneumonia. Respirol. Case Rep. 2021, 9, e00724. [CrossRef]

65. Wang, X.X.; Shao, C.; Huang, X.J.; Sun, L.; Meng, L.J.; Liu, H.; Zhang, S.J.; Li, H.J.; Lv, F.D. Histopathological features of multiorgan percutaneous tissue core biopsy in patients with COVID-19. J. Clin. Pathol. 2021, 74, 522-527. [CrossRef]

66. Zhou, G.; Dada, L.A.; Sznajder, J.I. Regulation of alveolar epithelial function by hypoxia. Eur. Respir. J. 2008, 31, 1107-1113. [CrossRef] [PubMed]

67. Schousboe, P.; Wiese, L.; Heiring, C.; Verder, H.; Poorisrisak, P.; Verder, P.; Nielsen, H.B. Assessment of pulmonary surfactant in COVID-19 patients. Crit. Care 2020, 24, 552. [CrossRef]

68. Islam, A.B.M.M.K.; Khan, M.A. Lung transcriptome of a COVID-19 patient and systems biology predictions suggest impaired surfactant production which may be druggable by surfactant therapy. Sci. Rep. 2020, 10, 19395. [CrossRef] [PubMed]

69. Piva, S.; DiBlasi, R.M.; Slee, A.E.; Jobe, A.H.; Roccaro, A.M.; Filippini, M.; Latronico, N.; Bertoni, M.; Marshall, J.C.; Portman, M.A. Surfactant therapy for COVID-19 related ARDS: A retrospective case-control pilot study. Respir. Res. 2021, 22, 20. [CrossRef]

70. Cattel, F.; Giordano, S.; Bertiond, C.; Lupia, T.; Corcione, S.; Scaldaferri, M.; Angelone, L.; De Rosa, F.G. Use of exogenous pulmonary surfactant in acute respiratory distress syndrome (ARDS): Role in SARS-CoV-2-related lung injury. Respir. Physiol. Neurobiol. 2021, 288, 103645. [CrossRef] [PubMed]

71. Ghati, A.; Dam, P.; Tasdemir, D.; Kati, A.; Sellami, H.; Sezgin, G.C.; Ildiz, N.; Franco, O.L.; Mandal, A.K.; Ocsoy, I. Exogenous pulmonary surfactant: A review focused on adjunctive therapy for severe acute respiratory syndrome coronavirus 2 including SP-A and SP-D as added clinical marker. Curr. Opin. Colloid Interface Sci. 2021, 51, 101413. [CrossRef] [PubMed]

72. Goldmann, M.A.; Luisada, A.A. Alcohol-oxygen vapor therapy of pulmonary edema. Ann. Intern. Med. 1952, $37,1221-1231$. [CrossRef]

73. Waugh, W.H. Potential use of warm butyl alcohol vapor as adjunct agent in the emergency treatment of sea water wet neardrowning. Am. J. Emerg. Med. 1993, 11, 20-27. [CrossRef]

74. Waugh, W.H. Adjuvant use of warm butyl alcohol vapor in experimental pulmonary edema. Life Sci. 1993, 52, 171-182. [CrossRef]

75. Jiang, X.W.; Gao, M.Z.; Liang, J.H. Experimental study on different concentration alcohol humidifying oxygen supply improving hypoxia caused by pulmonary edema. Zhonghua Hu Li Za Zhi 1996, 31, 373-376. (In Chinese) [PubMed]

76. The National Heart, Lung, and Blood Institute Acute Respiratory Distress Syndrome (ARDS) Clinical Trials Network. Comparison of two fluid-management strategies in acute lung injury. N. Engl. J. Med. 2006, 354, 2564-2575. [CrossRef]

77. Famous, K.R.; Delucchi, K.; Ware, L.B.; Kangelaris, K.N.; Liu, K.D.; Thompson, B.T.; Calfee, C.S.; ARDS Network. Acute respiratory distress syndrome subphenotypes respond differently to randomized fluid management strategy. Am. J. Respir. Crit. Care Med. 2017, 195, 331-338. [CrossRef]

78. Casey, J.D.; Semler, M.W.; Rice, T.W. Fluid management in acute respiratory distress syndrome. Semin. Respir. Crit. Care Med. 2019, 40, 57-65. [CrossRef] 
79. Barton, L.M.; Duval, E.J.; Stroberg, E.; Ghosh, S.; Mukhopadhyay, S. COVID-19 autopsies, Oklahoma, USA. Am. J. Clin. Pathol. 2020, 153, 725-733. [CrossRef]

80. Menter, T.; Haslbauer, J.D.; Nienhold, R.; Savic, S.; Hopfer, H.; Deigendesch, N.; Frank, S.; Turek, D.; Willi, N.; Pargger, H.; et al. Postmortem examination of COVID-19 patients reveals diffuse alveolar damage with severe capillary congestion and variegated findings in lungs and other organs suggesting vascular dysfunction. Histopathology 2020, 77, 198-209. [CrossRef]

81. Carsana, L.; Sonzogni, A.; Nasr, A.; Rossi, R.S.; Pellegrinelli, A.; Zerbi, P.; Rech, R.; Colombo, R.; Antinori, S.; Corbellino, M.; et al. Pulmonary post-mortem findings in a series of COVID-19 cases from northern Italy: A two-centre descriptive study. Lancet Infect. Dis. 2020, 20, 1135-1140. [CrossRef]

82. Navarro Conde, P.; Alemany Monraval, P.; Medina Medina, C.; Jiménez Sánchez, A.; Andrés Teruel, J.C.; Ferrando Marco, J.; Puglia Santos, V.; Mayordomo Aranda, E. Autopsy findings from the first known death from Severe Acute Respiratory Syndrome SARS-CoV-2 in Spain. Rev. Esp. Patol. 2020, 53, 188-192. [CrossRef]

83. Benumof, J.L. One-lung ventilation and hypoxic pulmonary vasoconstriction: Implications for anesthetic management. Anesth. Analg. 1985, 64, 821-833. [CrossRef]

84. Li, Y.; Tesselaar, E.; Borges, J.B.; Böhm, S.H.; Sjöberg, F.; Janerot-Sjöberg, B. Hyperoxia affects the regional pulmonary ventilation/perfusion ratio: An electrical impedance tomography study. Acta Anaesthesiol. Scand. 2014, 58, 716-725. [CrossRef]

85. Hartmann, E.K.; Duenges, B.; Boehme, S.; Szczyrba, M.; Liu, T.; Klein, K.U.; Baumgardner, J.E.; Markstaller, K.; David, M. Ventilation/perfusion ratios measured by multiple inert gas elimination during experimental cardiopulmonary resuscitation. Acta Anaesthesiol. Scand. 2014, 58, 1032-1039. [CrossRef]

86. Jaffal, K.; Six, S.; Zerimech, F.; Nseir, S. Relationship between hyperoxemia and ventilator associated pneumonia. Ann. Transl. Med. 2017, 5, 453. [CrossRef]

87. Wang, Z.; Yang, B.; Li, Q.; Wen, L.; Zhang, R. Clinical features of 69 cases with coronavirus disease 2019 in Wuhan, China. Clin. Infect. Dis. 2020, 71, 769-777. [CrossRef]

88. Dai, H.; Zhang, X.; Xia, J.; Zhang, T.; Shang, Y.; Huang, R.; Liu, R.; Wang, D.; Li, M.; Wu, J.; et al. High-resolution chest CT features and clinical characteristics of patients infected with COVID-19 in Jiangsu, China. Int. J. Infect. Dis. 2020, 95, 106-112. [CrossRef]

89. Li, X.; Marmar, T.; Xu, Q.; Tu, J.; Yin, Y.; Tao, Q.; Chen, H.; Shen, T.; Xu, D. Predictive indicators of severe COVID-19 independent of comorbidities and advanced age: A nested case-control study. Epidemiol. Infect. 2020, 148, e255. [CrossRef]

90. WHO. Clinical Management of Severe Acute Respiratory Infection when Middle East Respiratory Syndrome Coronavirus (MERS-CoV) Infection is Suspected (Interim Guidance). Available online: https://www.who.int/csr/disease/coronavirus_ infections/case-management-ipc/en/ (accessed on 15 April 2020).

91. BMJ Best Practice. Coronavirus Disease 2019 (COVID-19). Available online: https://bestpractice.bmj.com/topics/en-gb/300016 8/ (accessed on 18 August 2020).

92. The First Affiliated Hospital, Zhejiang University School of Medicine. Handbook of COVID-19 Prevention and Treatment. Available online: http:/ / che.zju.edu.cn/cheen/2020/0401/c27758a2021088/page.htm (accessed on 18 August 2020).

93. Jouffroy, R.; Jost, D.; Prunet, B. Prehospital pulse oximetry: A red flag for early detection of silent hypoxemia in COVID-19 patients. Crit. Care 2020, 24, 313. [CrossRef] [PubMed]

94. Siemieniuk, R.; Chu, D.K.; Kim, L.H.; Güell-Rous, M.R.; Alhazzani, W.; Soccal, P.M.; Karanicolas, P.J.; Farhoumand, P.D.; Siemieniuk, J.L.K.; Satia, I.; et al. Oxygen therapy for acutely ill medical patients: A clinical practice guideline. BMJ 2018, 363, k4169. [CrossRef]

95. Alhazzani, W.; Møller, M.H.; Arabi, Y.M.; Loeb, M.; Gong, M.N.; Fan, E.; Oczkowski, S.; Levy, M.M.; Derde, L.; Dzierba, A.; et al. Surviving sepsis campaign: Guidelines on the management of critically ill adults with coronavirus disease 2019 (COVID-19). Crit. Care Med. 2020, 48, e440-e469. [CrossRef]

96. Amodeo, L.R.; Wills, D.N.; Sanchez-Alavez, M.; Nguyen, W.; Conti, B.; Ehlers, C.L. Intermittent voluntary ethanol consumption combined with ethanol vapor exposure during adolescence increases drinking and alters other behaviors in adulthood in female and male rats. Alcohol 2018, 73, 57-66. [CrossRef]

97. Nentwig, T.B.; Starr, E.M.; Chandler, L.J.; Glover, E.J. Absence of compulsive drinking phenotype in adult male rats exposed to ethanol in a binge-like pattern during adolescence. Alcohol 2019, 79, 93-103. [CrossRef]

98. Hasanin, A.; Mostafa, M. Evaluation of fluid responsiveness during COVID-19 pandemic: What are the remaining choices? J. Anesth. 2020, 34, 758-764. [CrossRef]

99. Kallet, R.H. A comprehensive review of prone position in ARDS. Respir. Care 2015, 60, 1660-1687. [CrossRef] [PubMed]

100. Slutsky, A.S.; Ranieri, V.M. Ventilator induced lung injury. N. Engl. J. Med. 2013, 369, 2126-2136. [CrossRef]

101. Guérin, C.; Albert, R.K.; Beitler, J.; Gattinoni, L.; Jaber, S.; Marini, J.J.; Munshi, L.; Papazian, L.; Pesenti, A.; Vieillard-Baron, A.; et al. Prone position in ARDS patients: Why, when, how and for whom. Intensiv. Care Med. 2020, 46, 2385-2396. [CrossRef]

102. Hamilton, C.; Steinlechner, B.; Gruber, E.; Simon, P.; Wollenek, G. The oxygen dissociation curve: Quantifying the shift. Perfusion 2004, 19, 141-144. [CrossRef]

103. Dhont, S.; Derom, E.; Van Braeckel, E.; Depuydt, P.; Lambrecht, B.N. The pathophysiology of 'happy' hypoxemia in COVID-19. Respir. Res. 2020, 21, 198. [CrossRef] [PubMed]

104. Lin, L.; Lu, L.; Cao, W.; Li, T. Hypothesis for potential pathogenesis of SARS-CoV-2 infection-a review of immune changes in patients with viral pneumonia. Emerg. Microbes Infect. 2020, 9, 727-732. [CrossRef] 
105. Mannino, F.; Bitto, A.; Irrera, N. Severe acute respiratory syndrome coronavirus-2 induces cytokine storm and inflammation during coronavirus disease 19: Perspectives and possible therapeutic approaches. Front. Pharmacol. 2020, 11, 592169. [CrossRef] [PubMed]

106. Yuan, S.; Jiang, S.C.; Zhang, Z.W.; Fu, Y.F.; Hu, J.; Li, Z.L. Quantification of cytokine storms during virus infections. Front. Immunol. 2021, 12, 659419. [CrossRef] [PubMed]

107. Tavasolian, F.; Hatam, G.R.; Mosawi, S.H.; Saadi, M.I.; Abdollahi, E.; Jamialahmadi, T.; Sathyapalan, T.; Sahebkar, A. The immune response and effectiveness of COVID-19 therapies. Adv. Exp. Med. Biol. 2021, 1321, 115-126. [CrossRef] [PubMed]

108. Signorini, C.; Pignatti, P.; Coccini, T. How do inflammatory mediators, immune response and air pollution contribute to COVID-19 disease severity? A lesson to learn. Life 2021, 11, 182. [CrossRef] [PubMed]

109. Yokota, S.; Miyamae, T.; Kuroiwa, Y.; Nishioka, K. Novel coronavirus disease 2019 (COVID-19) and cytokine storms for more effective treatments from an inflammatory pathophysiology. J. Clin. Med. 2021, 10, 801. [CrossRef] 